\title{
A CRITICAL SURVEY OF CERTAIN PHASES OF TRIAL PROCEDURE IN CRIMINAL CASES.
}

In spite of frequent criticism of the administration of justice in criminal cases in the United States, we hear of no great wave of legislative reform, sweeping the country, for the improvement of existing conditions. Mr. Moorfield Storey has said in his "Reform of Legal Procedure," that "there is no part of its work in which the law fails so absolutely and so ludicrously as in the conviction and punishment of criminals and its failures in this respect endanger the whole foundation of society." Unfortunately this is too nearly the truth. The fact that our criminal procedure is being severely criticized, that reform is obviously in order, suggested to the writer the critical investigation of certain phases of trial procedure in criminal cases, which have been especially criticized, the results of which are now submitted for the consideration of the profession.

\section{Continuances.}

It is but fair that the defendant should have a reasonable time to prepare his case; that lie should not be forced to trial in the absence of his counsel, where such absence is unavoidable or without notice to him; that the case should not be tried in the absence of material witnesses, whose attendance either party has been unable to secure. So in the several States, by statute or decision the postponement of criminal trials for cause is permitted. The California Penal Code" provides that "When an action is called for trial or at any time previous thereto, the court may upon sufficient cause direct the trial to be postponed to another day." There are similar brief statutory provisions in a number of the States, while in others, there are many sections, specifying causes for which a continuance may be had and outlining in detail the procedure which is to be followed upon application for a continuance. The limits of this article will not pernit a discussion of nutters of purely local procedure. As to the

§IO52. 
grounds for which a continuance may be granted, it is submitted that the California statute is quite sufficient in providing that a continuance may be granted for sufficient cause, leaving the court to determine what cause shall be considered sufficient in the particular case. This is believed to be better than an attempt to enumerate all the conceivable circumstances which will make the granting of a continuance proper.

It is a very general rule that a motion for a continuance is addressed to the sound discretion of the court, under all the circumstances of the case; and while an appellate court will supervise the action of the trial court on such motion, it will not reverse, unless such action was plainly erroneous and manifestly uperated as a denial of justice. ${ }^{2}$ If there has been in fact an abuse of discretion, the appellate court will reverse the case. In Brown v. State, the defendant had been arrested in another county and brought to the county of trial, where he was confined in jail; he arrived there at night, and the following morning was brought into court for trial. From poverty he had been unable to employ counsel, and the judge appointed an attorney to represent him. The attorney, after a consultation of five minutes with the accused, reported to the court that the accused was not ready to go to trial; that counsel had had no opportunity to have witnesses subpoenaed, nor to examine the law of the case, and that no preparation whatever had been made for the defense. He asked the court to pass the case till the following morning, in ordet that he might send for witnesses and prepare the defense. The refusal of the continuance under these circumstances was held error.

Lack of preparation on the part of counsel has frequently been urged as ground for continuance, and may or may not move the court to exercise its discretion in granting it. It is quite clear, however, that the continuance will be refused if counsel is unprepared merely because of the pressure of other court work,

- Hite v. Commonvealth, 3 I S. E. Rep. 895 (Va. I898); Hamilton v. State, 62 Ark. 543 (1896); and sce also State v. Howard, 30 Mont. 518 (1904); State v. Underwood, 35 Wash. 55\$ (Ig04); State v. Douglas, 116 La. 524 (1906); Trask v. People, 15I IIl. 523 (1894).

I20 Ga. I45 (1904) and see Miller v. United States, 8 Okla. 315 (1899). 
rendering inconvenient his careful study of the case, ${ }^{4}$ or if the defendant has been himself negligent in procuring the assistance of counsel. 5 A refusal under these circumstances is not an abuse of discretion. The absence of counsel from the trial may be a good ground for continuance, as where defendant's counsel is absent on the morning of the trial without notice to him; but the absence of one of counsel is not good ground for continuance where other competent counsel are present. ${ }^{7}$

By statute in Tennessee the court may grant a continuance because of local prejudice and excitement which may harm the accused, ${ }^{8}$ and it has been held that this is a good ground for a continuance in the absence of such a statute, ${ }^{\theta}$ but this is not everywhere the rule, as it has sometimes been said that while popular excitement and prejudice may be ground for a change of venue, it certainly is not good ground for a continuance. ${ }^{10}$ In an appropriate case, ill health of the accused may be ground for a continuance, but as to the existence of this cause, like that of local prejudice and excitement, the court will usually receive affidavits or testimony in contradiction. ${ }^{11}$

Of the several causes for which continuances are granted, however, that most often alleged and most frequently the subject of abuse has been the absence of witnesses. Because so often alleged as a ground for continuance, and because of the tendency to ask a continuance on this ground without sufficient reason, courts and legislatures alike have been inclined to draw rather close restrictions about the granting of continuances for the absence of witnesses. So it has been held that the application for a continuance must show where the witness resides, if

- Baker v. State, IIr Ga. I4I (1900); Smith v. State, I32 Ind. I45 (1892).

- Moody v. Commonwealth, I9 Ky. L. Rep. 1198 ( 1897 ); State v. Inks, I35 Mo. 678 (1896).

- Leslie v. Commonwealth, 19 Ky. L. Rep. I201 (1897) ; see also Kuehn v. State, 47 Tex. Cr. 636 (1905).

'People v. Durant, rrg Cal. 20r (I897); Mason v. State, 8I S. W. Rep. 718 (Texas, 1904).

'Tennessee, Code of $1896, \$ 7172$.

- State v. Manns, $48 \mathrm{~W}$. Va. 480 (1900).

s" Siate v. Rice, 7 Idaho, 762 (I90r).

"Territory v. Shankland, 3 Ariz. 403 (1892); Lipscomb v. State, 76 Miss. 223 (18g8). 
his residence is known, ${ }^{12}$ the probability of securing the attendance of the witness by the next term, ${ }^{13}$ the facts constituting the diligence exercised to procure his attendance, ${ }^{14}$ the facts material to the case to which it is believed the witness, if present, would testify, ${ }^{15}$ and that there is no other witness by whom these facts may be so readily shown. ${ }^{10}$ An application is insufficient which merely states that "due diligence was used to procure the attendance of the witness" or that "the absent testimony is material to the case." General averments are insufficient. The facts constituting the alleged diligence must be stated, and the facts to which the witness would testify, in order that the court may determine whether there was due diligence and whether the absent testimony is in fact material.

Some very interesting questions have arisen as to what constitutes material testimony, for the absence of which a continuance should be granted. In Miller v. State ${ }^{17}$ the defendant was being tried for murder; the absent witness was one who was present at the shooting, and would testify that defendant did not fire the shot, but that it was fired by another person; that deceased was several hundred feet east of the dance hall when the shot was fired, and the accused was then in the back part of the lance hall, where he could not have fired the shot. The appellate court held the refusal of a continuarce error, the absent testimony being obviously material. In Allc v. State ${ }^{18}$ the testimony of the absent witness would have established an alibi, and the refusal of the continuance was held error. If the absent testimony, if procured, would be merely cumulative, there is no error

"Wiggins v. State, 1or Ga 502 (1897); State v. Hawkins, 2 Penn. 475

Donald v. State, 41 So. Rep. 4 (Miss. I906).

${ }^{23}$ Sims v. State, 45 S. W. Rep. 705 (Tex. 18g6); Easterlin v. State, 43 Fla. 565 (1901). (1905).

Puckett v. State, 71 Ark. 62 (1902); State v. Johnson, 70 Kan. 86I (Del. I900).

1 Mfiller v. State, 29 Neb. 437 (1890); Trim v. State, 33 So. Rep. 718 (Miss. 1903); State v. Penney, II3 Ia. 691 (1900).

" 29 Neb. 437 (1800).

"I 12 Ga. 752 (I000) : see also Thompson v. Siste, 78 S. W. Rep. 6ot (Tex 1904): Compton v. State, $108 \mathrm{Ga} .747$ (1809); Long v. State, 39 Tex. Cr. $46 \mathrm{r}$ (1898). 
in refusing a continuance, ${ }^{29}$ though it secms a distinction must be taken between evidence that is cumulative merely, and that which is corroborative. In Cathright v. State a prosecution for an assault with intent to commit murder, the defendant would testify to facts showing that he fired the shot in selfdefense; he asked a continuance for the absence of a witness who would testify to the same facts and would thus corroborate the testimony of the accused. The refusal of the continuance was held error. The absence of witnesses to prove character is not good ground for continuance, where other witnesses might be procured to testify in regard to it, ${ }^{21}$. and the same rule applies to experts who are out of the jurisdiction, where others might be called, of equal skill and experience. ${ }^{22}$ A continuance may also be properly refused where the proposed evidence would be inadmissible, ${ }^{23}$ or is probably untrue, ${ }^{24}$ or is obviously immaterial. ${ }^{25}$

Not only must the absent evidence be material; there must have been due diligence used to procure it. No hard and fast rule can be stated as to what constitutes due diligence, but a case or two may serve to illustrate the principle. In Benson v. State ${ }^{20}$ the homicide occurred on the evening of March 28. The accused was at once arrested, was indicted on the $29 t h$, and his case was set for trial April 4; immediately after procuring counsel, and as soon as he could learn of witnesses to the killing he applied for process, but was unable to procure the attendance of his witnesses by the day of trial. The court held this such reasonable diligence as entitled him to a continuance. But in

"Trim y. State, 33 So. Rep. 718 (Miss. 1903); Lively v. State, 73 S. W. Rep. 1038 (Tex. 1903). .

85 S. W. Rep. 10;6 (Tex. 1905).

- Jackson v. State, 62 S. W. Rep. 914 (Tex. 1901); Pratt v. State, 75 Ark. 350 (1905).

- Bush v. Commonwealth, 6 Ky. L. Rep. 51 (1884).

${ }^{2}$ Post v. State, 14 Ind. Ap. 452 (1895); Delk v. State, 99 Ga. 667 (1896); State v. Hollier, 49 La. An. 371 ( 1897$)$.

"State v. Demoss, 74 Kan. 173 (1906); Yancy v. State, 48 Tex. Cr. 166 (1905); State v. Timberlake, 50 La. An. 308 (1808).

- Grcenwood v. State, 44 Tex. 177 (1808); Carthaus v. State, 78 Wis. 560 (1891); Davids v. People, 192 III. 176 (1901).

${ }_{38}$ Tex. Cr. 487 (1897); see also Petit y. State, 135 Ind. 393 (1893); Williams v. State, 23 So. Rep. 547 (Miss. 3898); O'Rear v. Commonwealth, 78 S. W. Rep. 406 (Ky. 1904). 
Shiver v. State, ${ }^{27}$ where the defendant was arrested July 26,1898 , and the case was set for trial in March, 1899 , a failure to issue a subpoena for a material witness until February 28, 1899, was held such a lack of diligence that the refusal of an application for a continuance was not error.

The continuance has also been refused where it was improbable that the evidence would be procured; as where the absent witness was so infirm that there was no reasonable expectation of procuring her attendance, ${ }^{28}$ where the witness would incriminate himself by giving the proposed testimony, ${ }^{29}$ or where such witness was a fugitive from justice. ${ }^{30}$ Where the continuance is obviously asked only for delay, ${ }^{31}$ or is evidently not asked in good faith, ${ }^{32}$ it will not be granted.

Another general rule is this: even if the application for a continuance fulfills the usual requirements, yet the continuance will be refused if the opposing party will make certain admissions in regard to the absent testimony. In Kentucky and Indiana, at least, by statute, the opposing party must admit the truth of the facts alleged in the application for a continuance in order that the continuance may be refused, ${ }^{33}$ but in most. States, by decision or statute, it is not necessary that the truth of the testimony be admitted, but simply that the party admit that the absent witness, if present, would testify as alleged; such admission being made, the court must refuse to grant the continuance. ${ }^{34}$ On the trial evidence in contradiction may of course be introduced, or objection made as to the competency of the testimony. ${ }^{35}$

"4I Fla 630 (1899); see also Atkins v. State, 44 Tex. Cr. 201 (1902); Kidd v. State, zor Ga. 528 (1897); Davis v. Commonwealth, $6 \mathrm{Ky}$. L. Rep. 654 (1885).

- Brittain v. State, 40 S. W. Rep. 297 (Tex. 1897).

- Burns v. State, 51 S. W. Rep. 905 (Tex. 1899).

in Stevens v. State, 49 S. W. Rep. 104 (Tex. I\&99).

"State v. Jones, 53 W. Va. 613 (1903).

*State v. Dettmer, I24 Mo. 426 (I 894 ) ; State v. Belvel, 89 Ia. 405 (1893).

${ }^{23}$ Robinson v. Commonwcalth, 24 Ky. L. Rep. 564 (1902) ; Miller v. State, o Ind. 340 (1857); State v. Schoonorer, 21 Ind. Ap. 520 (I899).

${ }^{31}$ Russel v. State, 62 Neb. 512 (IgOI); Thompson v. State, 5 Kan. 159 ( 1859 ) : State v. St. Clair, 6 Ida. Iog (ISg8); People v. Savant, irz Mich. $2,187(189)$. (1905).

ss State v. Leuhrsman, 128 Ia. 476 (1904); State v. High, 116 Ia. 79 
Q

Because of the frequency with which the absence of witnesses is alleged as ground for continuance, and the abuse which has prevailed in regard to it, it is undoubtedly advisable to hedge about the granting of continuances on this ground with very necessary safeguards, and it is believed that the Wyoming statute ${ }^{36}$ does this more completely than any others. It is as follows:

"A motion to postpone the trial of a case in any of the courts of this state, on account of the absence of evidence, can be made only upon affidavit showing the materiality of the evidence expected to be obtained, and that due diligence has been used to obtain it, and where the evidence may be; and, if it is for an absent witness, the affidavit must show where the witness resides, if his residence is known to affiant, and the probabilities of procuring his testimony within a reasonable time, and that his absence has not been procured by the act or connivance of the party, nor by others at his request; nor with his knowledge or consent, and what facts he believes the witness will prove, and that he believes them to be true, and that he is unable to prove such facts by any other witness whose testimony can be as readily procured. If thereupon the adverse party will consent that, on the trial, the facts stated in the affidavit shall be taken as true, if the absent evidence is written of documentary, and in case of a witness that he will testify to the facts stated in the affidavit as true, the trial shall not be postponed for that cause; and, in such case, the party against whom such evidence is used shall have the right to impeach the evidence of such absent witness, as in case where the witness is present or his deposition is used."

It will be noticed that this statute applies the rule to absent evidence, written or documentary, as well as to absent witnesses.

The amendment of an.application for a continuance is usually not allowed; if permitted at all it is held to be entirely within the discretion of the trial court. ${ }^{37}$. The court may also, after granting a continuance, vacate its order; at least unless setting aside the continuance operates unfavorably to the interests of the party applying therefor. ${ }^{38}$ It is usually held that the defendant need not be present at the hearing of the application, ${ }^{39}$ as will be seen in a subsequent section of this article.

* Compiled Statutes, 1910, \$5139.

"State v. Good, 132 Mo. II4 (1895).

* Sampson v. Pcople, I88 IIl. 592 (190r).

- O'Boyle v. Commonwealth, Im Va. 785 (Ig0I); Kibler v. Commonwealth, 24 Va. 804 (1897); State v. Hall, 189 110. 262 (1905). 
There is some difference of opinion as to whether a continuance having been applied for by affidavit, counter affidavits may be received to show that it should not be granted. In a few States counter affidavits are improper for any purpose, but by the weight of authority they may be received, at least to show want of diligence in procuring the testimony of an absent witness, or want of good faith in the application, to show that it is improbable that the proposed testimony can be obtained, to con: tradict an averment that a witness or counsel who is absent is sick, or to dispose of the allegations of public excitement or prejudice. ${ }^{10}$ To prevent any imposition upon the court, it seems only right and proper that counter affidavits should under such circumstances be receivable to show that the continuance should not be granted.

\section{Custody and Restraint of Defendant.}

The common law rule was that "although under an indictment of the highest nature, the prisoner must be brought to the har without irons or any manner of shackles or bonds, unless there be evident danger of an escape, and then he may be secured with irons."11 In accordance with the principle thus expressed, it is provided by statute in many States that "a person charged with a public offense shall not before conviction be subjected to any more restraint than is necessary for his detention to answer the charge." The earliest American case on the subject appears to be Pcople v. Harrington. ${ }^{42}$ In that case, a prosecution for robbery, when the jury were sworn, the defendants were in court and in irons. Their counsel asked that the irons be removed during the trial, but the court refused to order this done, being of the opinion that no rights of the defendants were violated by their being tried in irons without their consent. The appellate court,

"Shoun v. State, 211 Tenn. 166 (1903); Lane v. State, 67 Ark. 290 (180) ) ; Ransom v. State, ;o S. W. Rep. yso (Tex. 1902); Halierman v. Territory, 7 Ariz. 320 (1900): Territory Y. Shankland, 3 Ariz. 403 (1892). See also ficorgia Code, 1911, Vol. 1I, \$m2: "The presiding judges may in their discretion admit a connter showing to a motion for a continuance, and after a hearing may decide whether the motion shall prevail."

it 4 Rlack. Com. 322; and see 2 Hale P. C. 219; Kely. 7, yo.

* Cal. 165 (1871). 
after conviction. granted a new trial, holding that any order or action of the court which without evident necessity imposes physical burdens, pains and restraints upon a prisoner during the progress of his trial, inevitably tends to confuse and embarrass his mental faculties and thereby materially to abridge and prejudicially affect his constitutional rights and is a direct violation of the common law rule and of the Criminal Practice Act.

Where there is such "evident necessity" for shackling the defendant, such restraint as is necessary may be imposed, and whether such necessity exists or not, it is largely within the discretion of the trial court to determine. In Faire v. State, ${ }^{43}$ during the trial, prisoner's counsel discovered for the first time that the defendant, who sat in full view of the jury during the whole trial, was shackled with leg irons; counsel objected, moving to have the irons removed. But the sheriff having explained to the court reasons for believing the defendant would escape, or at least create a scene in the court room unless secured, the motion was overruled. The court held:

"It requires an extreme case to justify shackles or manacles on a prisoner undergoing trial, but whether or not this is necessary must be left to the enlightened and conscientious discretion of the lower court in view of all the circumstances of the particular case."

So a desperate defendant, it is held, may be shackled in going to and from the cotirthouse and the shackles be removed and put on before the jury; ${ }^{41}$ a fugitive from justice or prisoner likely to escape may be properly secured ;5 and where a dangerous character was on trial for murder in the first degree, it was held not improper to maintain an armed guard over him during the entire trial. ${ }^{48}$

- Even in the absence of such evident necessity, the rule has not always been strictly applied. In State v. Allen ${ }^{47}$ the defend-

- j8 Ala. 74 (1877).

"State v. Temple, 194 Mn. 228 (1905). $1882)$.

4 Upstone v. Pcople, 109 lil. $169\left(188_{3}\right)$; Poe v. State, 10 Lea, 673 (Tenn.

- State v. Dincan, 116 Mo. 288 (1893).

" 45 W. Va. 66 (18g8). 
ant was manacled during a part of the trial, but the monent the matter was brought to the attention of the court, the manacles were ordered removed and were at once removed in the presence of the jury. The court refused to set aside a conviction, as it was quite obvious that under all the circumstances no harm could possibly have come to the defendant. In Vcla v. State ${ }^{18}$ the defendant did not object at all to his shackles during trial, and failed to show that he was harmed by being shackled; the appellate court refused to disturb the conviction.

In many cases, however, because of the imposition of what the court considered undue restraint, new trials have been granted. The case most often cited in this connection is State v. Kring. ${ }^{49}$ The record showed that the court having directed the trial to proceed, the defendant, who was ironed with handcuffs, by his counsel moved the court to have his manacles removed. This the court refused to do, overruling the motion. The appellate court held:

"It was not pretended in this case that there was danger of an escape. Had this danger existed, however, we are of the opinion that it would have been error, even then, to keep the prisoner's hands fettered in the presence of the jury during the trial of the case."

The rule here stated goes too far, limiting the discretion of the court even in cases where it may be advisable to have the defendant securely shackled. In other cases, while the proposition has not been quite so. emphatically stated, judgment has been reversed because the defendant was subjected to restraint during his trial, entirely without inquiry as to whether he was harmed by the proceedings, ${ }^{50}$ and even in the absence of objection thereto. ${ }^{51}$ It is submitted that in all such cases, the court should be permitted to inquire into the question of prejudice to the accused and should not grant new trials unless prejudice has resulted. Legislation

${ }^{4} 33$ Tex. Cr. 322 (1804); and see Burks v. State, 50 Tex. Cr. 47 (1906); Matthews : State, 2 Lea, 128 (Tenn. 1882); Canon v. State, 59 Tex. Cr. 398 (1910); Rainey v. State, 20 Tex. Ap. 455 (1886).

"67 Mo. $591(1877)$. (I897).

State v. Smith, II Ore. 205 (1883); State v. Williagrs, 18 Wash. 47

"Lice v. State, 51 Miss. 566 (1875). 
bringing about this result is advisable. Let the direction be that defendant be not unduly restrained; but if through mistake or inadvertence, or even intentionally, the trial court fail to order his shackles to be removed during the trial, let no new trial be granted unless the defendant has been actually prejudiced by the action of the court.

\section{Presence of Defendant.}

Formerly in England, counsel might represent a prisoner in trials for treason or for misdemeanor, but not in trials for felony; as the accused in such cases could only defend himself, it was held that he must be present in court whenever any step was taken in his case, however insignificant or unimportant. The old English cases on this subject were very strictly followed in the early jurisprudence of America, and in adhering blindly and tenaciously to the rule that defendant must be present during his trial for felony American legislatures and courts have lost sight of the reason upon which it was founded. The right of the defendant to be present during his trial for a criminal offense is not expressly given by our constitutions. Some of the courts, which have declared that the accused has such a right and have based their claim upon constitutional grounds, found their arguments upon the constitutional provisions that the defendant shall have a right to be heard by himself and by counsel, and that he shall have $a$ right to meet the witnesses face to face.

An examination of the statutes now existent in this country reveals a rather general rule that if the prosecution be for felony, the defendant must personally be present during the trial, but if for misdemeanor, the trial may be had in his absence. As to misdemeanors, it is variously provided that the defendant, at his own request and by leave of court, may be tried in his absence; or that if the defendant is not himself present, he must appear by counsel; or that if the defendant's presence is necessary for the purpose of identification, he nay be required to attend. Several States have also provided by statute that the defendant must appear in. person before the verdict is received in felony cases, but need not in prosecutions for misdemeanor. Texas ${ }^{52}$ requires

"Revised Criminal Statutes, I9II, \$769. 
presence of the defendant at verdict in felony, unless he have escaped after the commencement of the trial. In Missouri ${ }^{52}$ a verdict may be received in defendant's absence, whenever such absence is willful or voluntary. The following rather unusual provisions may be noted: In Mississippist in criminal cases the presence of the prisoner may be waived and the trial progress at the discretion of the court, if he be in custody and consenting thereto; in Ohio ${ }^{55}$ if a person indicted escape or forfeit his recognizance after the jury is sworn, it is provided that the trial shall nevertheless proceed, and the verdict be received and recorded; in Arkansas ${ }^{56}$ if the defendant escape from custody after the trial has commenced, or if, being on bail, he absent himself during his trial, the trial may either be stopped, or progress to a verdict, at the discretion of the prosecuting attorney. In the Codes of Canada and New Zealand may be found the following exceptional provision:

"The court may permit the accused to be out of court dur-. ing the whole or any part of the trial on such terms as it thinks proper."

Such a clause is not found in any of the American statutes.

In misdemeanors, then, the trial may in general be had ${ }^{58}$ and the verdict received ${ }^{59}$ in the absence of the defendant. It cannot be said, however, that the defendant has a right in such cases to be tried in his absence; it is for the court to determine, in the exercise of its sound discretion, whether the trial may proceed in the absence of the accused, or whether he shall be required to attend; the exercise of this discretion by the trial court will not be reviewed on appeal, unless there has been a palpable abuse. ${ }^{.0}$

* Annotated Statutes, 1906, Vol. II, \$2610.

"Code, 1906, \$1495.

Code, 1910, Vol. III, \$13676.

* Digest of Statutes, 1904, \$2339.

"Canada, Revised Statutes, 1906, Vol. 3, §943; New Zealand, Consolidated Statutes, Vol. I, \$433.

ss State v. Lucker, 40 S. C. 549 (1893) ; People v. Butd, 57 Cal. 349 (1881). (1847).

"Gage v. State, 9 Tex. Cr. 259 (1880); Holliriay v. People, 9 Ill. III

'State y. rr+rland, 67 Me. 423 (1877); Owen v. State, 38 Ark. 512 (1882);
Bridges v. State, 38 Ark. 510 (1882). 
Whether the entire trial may be had in the absence of both defendant and his counsel depends upon the phraseology used in the statute; under some of the statutes and decisions rendered under them, the trial may be had in the absence of the defendant only if he appear by counsel. ${ }^{.2}$

In the trial of felonies, the defendant has a right to be present "during trial." It immediately becomes necessary that we understand the meaning of this phrase and determine whether every step in the proceeding, however trivial, is important enough to require his presence. The absence of the defendant has been held error during the impanelling and selection of the jury, ${ }^{82}$ the examination of witnesses, ${ }^{63}$ the argument of counsel, ${ }^{\text {,4 }}$ the charge of the court or giving of additional instructions or reading evidence to the jury after retirement, ${ }^{05}$ the rendition of the verdict, ${ }^{\text {es }}$ and the discharge of the jury. ${ }^{67}$ But it is generally held to be immaterial if the defendant is absent at proceedings preliminary or subsequent to the trial proper, or not amounting to substantive steps in the case, ${ }^{68}$ such as the amendment of an indictment, the making of an order setting the date of trial, the drawing of a special venire from the jury box, the appointment of counsel to assist in the prosecution, the hearing of an application for the attachment of a witness, the recognizance of witnesses to appear in another court, or amendment of the verdict. Motions to

State v. Young, 86 Ia. 406 (1892); Lawn v. People, II Col. 343 (1888).

- Lewis v. United States, I46 U. S. 370 (1892).

* Bearden v. State, 44 Ark. 33I (1884); Bennett v. State, 62 Ark. 5I7 (1896); Burton v. State, 46 Tex. Cr. 493 (1904); State v. Sheppard, 49 W. Va. 582 (IgOI).

* Tiller v. State, $96 \mathrm{Ga} .431$ (1895); Rose v. State, 20 Ohio, 31 (185I).

- State v. Blackwelder, 6I N. C. 38 (1866) ; People v. Kohler, 5 Cal. 72 (1855); Jones v. State, 26 Ohio St. 208 (1875); State v. Meagher, 49 MLo. Ap. 57I, 581 (1892) ; Witt v. State, 5 Cold. II (Tenn. I867).

* People v. Perkins, I Wend. 9r (N. Y. 1828); State v. Buckner, 25 Mo. 167 (1857); State v. Hughes, 2 Ala. I02 (I84I).

" State v. Smith, 44 Kan. 75 (1890); State v. Spores, 4 Ore. 198 (1871); State v. Muir, 32 Kan. 481 (1884).

- State v. Dominique, 39 La. An. 323 (1887) ; State v. Abrams, 8 Pac. Rep. 327 (Ore. 1883); Hurd v. State, 116 Ala. 440 (1897); Hall v. State, 132 Ind. 317 (1892); State v. Simien, 36 La. An. 923 (1884); Bolling v. State, 54 Ark. 588 (1891); Mc.Namara v. State, 60 Ark. 400 (1895). But cf. Sylvester v. State, 7I Ala. 17 (188I); Baker v. State, 39 Ark. 180 (I882); Brown v. State, 38 Tex. 482 (1873). 
quash an indictment, for a continuance or change of venuc, for a new trial or in arrest of judgment, are not by most courts considered of such importance as to require the presence of the defendant during their determination, ${ }^{68}$ but as to these proceedings the cases are not entirely in accord. ${ }^{70}$

The absence of the defendant at the discharge of the jury is in some jurisdictions more serious than at any other time during the trial; an absence at other times is but ground for a new trial; but where the defendant is absent when the jury are discharged, it has been held that the discharge, being improper, works an acquittal of the accused, whether it be discharged before verdict, ${ }^{71}$-as for illness of a juror, inability of the jury to agree, or other cause, - or a discharge upon rendition of the verdict. ${ }^{72}$ In Brister v. State, ${ }^{73}$ when the jury returned with their verdict the prisoners were not in court but in jail, though the court did not know this; the clerk was directed to receive the verdict, and did receive it and read it aloud in the presence of the court; the court then told the jury they were discharged, but notieing immediately that the prisoners were not present, told the jury they were not discharged, before they left the box. The sheriff was told to bring in the prisoners; when they were brought it, they objected to the reception of the verdict, but the objection was overruled and the verdict received. It was held that the court's revocation of the discharge was in time.

The courts are fairly well agreed that the defendant has a right to be present during the more important steps in the trial; they do not agree as to the less important steps which we have discussed. Statutes not providing that the defendant has a right to

- Epps v. State, I02 Ind. 539 (I885); State v. Atkinson, 40 S. C. 365 (1893); Kibler v. Commonwealth, 94 Va. 804 (1897), but cf. Shelton v. Commonwealth, 89 Va. 450 ( 1802 ); State v. Elkins, 63 Mo. 159 (1876); Jones v. State, 152 Ind. 318 (1898); People v. Ormsby, 48 Afich. 495 (1882); State v. Jefcoat, 20 S. C. 383 (1883); Ward v. Territory, 8 Okla. 12 (1899).

${ }^{\circ} \mathrm{Cf}$. contra to cases cited in note 69 : State v. Clifton, $57 \mathrm{Kan} .448$ ( 1896 ); Ex parte Bryan, 44 Ala. 402 (1870); Gibson v. State, 3 Tex. Cr. 437 (I878). "Upchurch v. State, 36 Tex. Cr. 624 (1896); State v. Wilson, 50 Ind. 486 (1875); State v. Sommers, 60 Minn. 90 (1895).

"Nolan v. State, $55 \mathrm{Ga}$. 521 (18;5); State v. Hays, 2 Lea, 156 (Tenn. $1879)$, but $c f$. cases cited in note 67 , where only a new trial was granted. (1895).

1226 Ala. 107 (1855). And see in accord, State v. Hutchinson, 95 Ia. 566 
be or must be present "during trial," a phrase that has been given a variety of definitions, but naming the various steps in the proceeding during which he has a right to be present, would bring about greater uniformity of decision and would be for that reason advisable.

An absence is usually taken to mean an absence from the courtroom, but this is not necessarily the case. In Crozvell $\mathbf{v .}$ Pcople, ${ }^{74}$ after the jury had been out two hours, they were brought into court by the officer and at their request for an instruction as to the nature of the punishment, the court gave them the instruction. The defendant was in the courtroom, but was sick, and was lying on a bench fifty ieet from the judge. The instruction was read loud enough to be heard all over the courtroom. It was held that the objection that the instruction was given in the absence of the defendant was not well taken. But in State v. Mannion $^{75}$ a prosecution for assault with intent to commit rape, when the prosecuting witness expressed a fear at testifying before the defendant, the court required him to take a seat in a part of the courtroom away from the jury and witness, where he could neither hear said witness, nor could he see her nor the jury while she was testifying. This was held an infringement of the defendant's right to be present during his trial, and a new trial was granted.

The defendant cannot object that he was not present at the trial of his co-defendant $;^{78}$ nor can he object to the absence of his counsel during his own trial; the absence of counsel even during substantive steps in the proceeding is usually held not to be error. ${ }^{77}$

It has been said that the defendant has a right to be present during a trial for felony; in this connection we must discuss a further question: May the defendant waive the right to be present? There is the highest authority for saying that the right cannot be waived, even by the express consent of the accused. in

\footnotetext{
"190 III. 508 (1901).

"19 Utah, 505 (3899).

- People v. O'Brien, 88 Col. 483 (1891).

* Maker v. State, 58 Ark. 51.3 (1894); Richarison v. State, 7 Tex. Ap. $436(1879)$.
} 
a capital case, ${ }^{78}$ and in favor of life, this would seem to be a proper restriction of the doctrine of waiver. But in cases less than capital, though a few courts have said that the defendant cannot waive the right to be present, ${ }^{79}$ the defendant, according to the weight of authority, may waive the right, either expressly, ${ }^{80}$ or by absconding or otherwise voluntarily absenting himself during the trial. In Sahlinger v. People ${ }^{81}$ the defendant was tried with others for larceny; he voluntarily absented himself from the courtroom before the conclusion of the trial, at the time the instructions were given, and later when the verdict was received. It was held:

"There is no doubt but that a prisoner on trial for a felony has the right to be present at every step taken in his case, and it would be error for the court to deprive him of that right without his consent, unless it might become necessary to remove him from the courtroom temporarily for disorderly conduct; but where a prisoner after a trial has begun, wrongfully and voluntarily abandons the courtroom and refuses to appear, he must be regarded as having waived a right which is guaranteed to him if he sees proper to avail of it, and the court is under no obligations to stop the trial until the defendant thinks proper to return, but in such a case the court would not transcend any of its legitimate powers by proceeding with the case to final judgment."

Again, in Falk v. United States, 82 the court held:

"The rule to be derived from the authorities is that in all cases involving less than capital punishment ... when a trial has been once begun, the flight or escape of the accused person does not preclude the court from proceeding with the cause and receiving the verdict of the jury in the absence of the defendant, so caused by his wrongful act."

"Hopt v. Utah, r1o U. S. 574 (I883); Jackson v. Commonwealth, 19 Grat. 656 (Va. 1870); Gladden v. State, 12 Fla. 562 (1868).

- Sneed v. State, 5 Ark. 43I (1844); Andrews v. State, 2 Sneed, 550 (Tenn. 1855); Summerals v. State, 37 Fla. 163 (1896).

- Cawthon v. State, Irg Ga. 395 (1903).

" 102 IIl. 241 (1882). See also People v. Bragle, 88 N. Y. 585 (1882); State v. Gonce, 87 Mo. 627 (1885); State v. Ellvin, 5I Kan. 784 ( I893); Killman v. State, 53 Tex. Cr. $5 ; 1$ (I908); Lynch v. Commonwealth, 88 Pa. 189 (1878); Hill v. State, 17 Wis. 675 (1864); Barton v. State, 67 Ga. 653 (1881); Frey v. Circuit Judge, 107 Afich. 130 (1895).

I5 App. Cas. D. C. 446 (1899). See also Gore v. State, 52 Ark. 285 (1889); Fight v. State, 7 Ohio, 181 (1835); State v. Hope, 100 Mo. 347 (1889); State v. Kelly, 97 N. C. 404 (1887). 
By statute in Queensland"s it is provided that "the trial must take place in the presence of the accused person, unless he so conducts himself as to render the continuance of the proceedings in his presence impracticable, in which case the court may order him to be removed, and may direct the trial to proceed in his absence." There appear to be no such statutes in any of our States, and the question suggested by that quoted has seldom arisen in the cases. In United States v. Davis ${ }^{84}$ the defendant persisted in interrupting proceedings by denying in a loud voice statements made by the district attorney in his opening address. The court admonished him to refrain, but since the action of the prisoner made it impossible to proceed with the trial with due decorum, he was ordered removed and the trial proceeded during that day in his absence; next day, when the prisoner was more composed, the trial was continued in his presence. The action of the trial court in causing the prisoner to be removed during trial being subsequently brought in question, the higher court held:

"The right of a prisoner to be present at his trial does not include the right to prevent a trial by unseemly disturbance. The defendant had an opportunity to be present at the whole of his trial. He was absent during a part of the opening only because of his own disorderly conduct. It does not lie in his mouth to complain of the order which was made necessary by his own misconduct, and which he could at any time have terminated by signifying his willingness to avoid creating a disturbance."

The conduct of the accused in this case may, perhaps, be regarded as constituting a waiver of his right to be present.

It has been held that, the defendant being absent, the mere presence of his counsel during the trial, does not amount to a waiver of the right to be present, ${ }^{85}$ and while in Georgia it is held that counsel may expressly waive this right of the accused, ${ }^{80}$

"Pub. Gen. Statutes, Vol. I, \$617. Similarly, Canada, Revised Statutes, 1906. Vol. III, \$943; New Zealand, Consolidated Statutes, Vol. I, \$433.

" 6 Blatch. ${ }_{4} 64$ (1869). See also Regina v. Berry, 104 Law Times, 110 (Eng. 1898).

"Shipp v. State, II Tex. Cr. 46 (188I); Rose v. State, 20 Ohio, 3I (18,5): Roberts v. State, III Ind. 3.10 (1887); Cook v. State, 60 Ala. 39 $(18 \%)$.

* Hill v. State, 118 Ga. 21 (Ig03); Cawthon v. State, IIg Ga. 395 (1903). 
according to the weight of authority, even an express waiver by counsel for the accused is ineffective, and is not binding upon him; this appears to be the general rule, even in States which permit a waiver by the defendant himself. 87

While, under our constitutions, it is probably necessary to uphold the right of the defendant to be present when any substantive steps are taken in a proceeding against him, he should certainly be held to have waived this right by any willful or voluntary absence, or by misconduct necessitating his removal. Perhaps our legislatures and courts would not go too far in supporting the proposition that a waiver may be made by counsel, and if so made, it will be as effective as if made by the accused himself, at least, unless the latter is able to show that he was prejudiced by such waiver.

- There is a difference of opinion as to the effect of an involuntary absence of the accused during a part of his trial. In Cason v. State ${ }^{88}$ a witness was asked several important questions in the defendant's absence, but, as soon as the court discovered the absence, the jury were told to disregard everything that had just been said; the defendant was brought in, and the witness re-examined; the court held that there were no grounds for reversal. On the other hand, in State v. Sheppard ${ }^{89}$ the following questions and answers were received from a witness during an enforced absence of the defendant:

"Q. What is your name, please? A. Flora Ayers. Q. What is your husband's name? A. Jont Ayers."

The absence of the prisoner being then for the first time brought to the attention of the court, the trial was stopped until he was brought in, whereupon the same questions were asked and the same answers received. The court granted a new trial, regarding it

"Martin v. State, 40 Ark 364 (1883); State v. Myrick, 38 Kan. 238 (r888) ; Nomaque v. People, Breese, Iog (III. I825); Prine v. Commonwealth, $18 \mathrm{~Pa}$. 103 (1851).

" 52 Tex. Cr. 220 (1907) ; State v. Paylor, 89 N. C. 539 (1883); State v. Spotted Hawk, 22 Mont. 33 ( 1899 ); People v. LaMunion, 64 Mich. 709 (I887).

49 W. Va. 582 (I50I); State v. Greer, 22 W. Va. $800^{4}(1883$ ); Tiller v. State, $96 \mathrm{G}_{2} 431$ (1895). 
as immaterial that the defendant could not have been prejudiced by what occurred during his absence, and declaring "It was clearly a matter of no consequence that the evidence introduced in this case in the absence of the prisoner may not have affected him, and that he did not at the time take an exception." If, during an involuntary absence of the defendant, an irregularity obviously prejudicial to him occur, a new trial will everywhere be granted. If there be no such irregularity, we encounter the difference of opinion indicated by the cases above cited; the better rule would seem to be that unless there be a showing of prejudice, no new trial should be granted, even for an involuntary absence of the accused during trial. It is very doubtful, however, whether the more conservative of our courts would hold constitutional a statute so providing, as it would undoubtedly be argued that such a rule would deprive the defendant of his right to be heard by himself and counsel and to be confronted with the witnesses against him.

The presence of the accused is of course unnecessary in the appellate court. On writ of error to reverse a judgment in even a capital case, the personal attendance of the defendant at the argument or at the decision of the court is not necessary to give such court jurisdiction. 00

The courts have not agreed as to what the record must show in regard to the defendant's presence during trial. In some jurisdictions it is held that it must affirmatively appear of record that the defendant was present where his presence is necessary. Under this view it would not be sufficient for the record to show the presence of the defendant at the beginning and at the conclusion of the trial; it must affirmatively appear that he was present at each substantive step in the proceeding. ${ }^{91}$ In Day v. Territor $y^{92}$ the court said:

"It may be and more than likely is true, that the defendant was in fact present at all times and that the error is an inad-

\footnotetext{
- People v. Clark, I Park. Cr. 360 (N. Y. 1852); Fielden v. People, I2 III. 595 ( 1889 ).

"Dougherty v. Commonwealth, $69 \mathrm{~Pa}$. 286 (1871); State v. Christian, 30

La. An. 367 (18;8).

$n_{2}$ Okla 409 (1894).
} 
vertence in making up the record when his case was called for consideration; but it would be a dangerous precedent to establish for the court to assume such to be the truth, and thus give its assent to a conviction where the record fails to show that the defendant was actually present."

In other States it is held sufficient if the presence of the defendant can be gathered from the record by fair intendment or by necessary and reasonable implication; if, therefore, it appears that the defendant was present at the beginning of the trial, which by the record is shown to have proceeded without interruption, the presumption follows that he was present during the remainder of it, unless the contrary appear affirmatively of record..$^{\text {ss }}$ The third view is that the presence of the accused during the trial will bepresumed unless the contrary appear affirmatively of record; a record that is entirely silent as to whether or not the defendant was present during his trial would be sufficient only under this view. ${ }^{94}$ It is suggested that this view is the most logical of all, inasmuch as it would prevent the granting of many new trials by simply indulging in a presumption that proceedings in the trial court have been entirely regular.

\section{Presence of Judge.}

It has been laid down as a general rule in many jurisdictions that the presence of the judge at every stage of the trial is essential to the validity of the proceedings; if he absent himself and any part of the trial be conducted in his absence, a conviction cannot be sustained. This rule is not a statutory one in any of our States; it is a rule by decision, and its extent, as well as the nature of the exceptions and qualifications that have been engrafted upon it in some jurisdictions, can be learned only by an examination of the cases.

The reasons for the rule have been variously stated. It has been said that the judge should be present during every stage of

\$Brown v. State, z9 Fla. 543 (1892); Burney v. State, 32 Fla. 253 (1893); Schirmer v. People, 33 Ill. 2,66 (1564); State v. Allen, 45 W. Va. 65 (1898); State v. Costello, 29 W ash. 366 (1902). (1878).

State v. Daugherty, 63 Kan. 473 (1901); Smith v. State, 60 Ga. 430 
the proceeding, as the defendant will otherwise be unable to object to such irregularities as may occur during the absence. ${ }^{95}$ The presence of the judge has also been said to be necessary in order that he may intelligently decide a motion for a new trial after verdict, ${ }^{90}$ and because his immediate presence tends to preserve the legal solemnity and security of trial, and upholds the majesty of the law. ${ }^{97}$ But the reason most frequently given is that the defendant has a constitutional right to a trial before a court duly constituted; that there can be no court without a judge, and his absence during any part of the trial works a disorganization of the court, so that further proceedings are void and of no effect. ${ }^{98}$

The courts agree that the judge may change his seat in the courtroom during the trial, or he may read or write or engage temporarily in conversation. ${ }^{00}$ Indeed, his presence is sometimes construed to mean not absolutely within the courtroom, but so near as to be within sight and hearing of the proceedings; that is, in such a situation as to retain control of all that occurs during thie trial. ${ }^{100}$ So in Graves v. People $e^{101}$ the court held:

"While we do not say that every brief absence of a judge from the courtroom, where he both sees and hears all that is done, and can himself be seen and heard, necessarily constitutes reversible error; yet, to be justified, the judge during such absence, must not only be within hearing but within sight of counsel and jury, and in such a position that he may be seen and heard by them and able instantly to interpose his authority in preserving decorum in the courtroom, and to pass upon questions as they arise and assert and maintain that full control over the trial which is so essential a part of due process of law."

" Carney v. State, 47 Tex. Cr. 566 (1905).

- Slaughter v. U. S., 5 Ind. Ter. 234 (1904); State v. Beuerman, 53 Pac. Rep. 874 (Kan. 1898).

"Hayes v. State, $58 \mathrm{Ga} .35$ (1877) ; O'Brien v. People, 17 Col. 561 (1892).

* Ellerbe v. State, 75 Miss. 522 ( 1897 ); Graves v. People, 32 Col. 127 (1904); Penple v. Tupper, I22 Cal. 424 (18gS); State v. Beuerman, 53 Pac. Rep. 874 (Kan. 1898); State v. Carnagy, $106 \mathrm{I}_{2} 483$ (1898).

- State v. Carnagy, 106 Ia. 483 (1898).

ine Mijler v. State, 73 Ohio St. 195 (1906); Rutter v. Territory, 11 Okla. 454 (1902). And see State v. Porter, $105 \mathrm{Ja} 677$ (1898), and State v. Smith, 49 Conn. $3 ; 6(1881)$. where it was held no error for the judge to be without the court roum, out of sight, but within hearing of the proceedings.

in 32 Col. 127 (1904). 
While all of our courts regard an absence of the judge during the trial as highly improper, they do not agree as to the effect of the absence. If, during the absence, some irregularity occurs obviously prejudicial to the defendant, it is well settled that a conviction will be set aside; so in Slanghter v. United States, ${ }^{102}$ where the judge went into his chambers for approximately one minute, but during his absence counsel for the government made improper and misleading remarks to the jury, and in Turbeville v. State, ${ }^{103}$ where during the absence of the judge the district attorney in his argument appealed to the race prejudice of colored jurors.

If it be not shown that defendant was prejudiced by some irregularity occurring during the absence of the judge, there is a difference of opinion as to whether a new trial will be granted. The weight of authority undoubtedly supports the proposition that an absence of the judge during the trial is error regardless of prejudice to the defendant; in other words, prejudice will be presumed. This is clearly the position taken in Bateson v. State, ${ }^{104}$ where it was held that if the judge by his absence "loses that control and supervision of the court which is so necessary to safeguard every right of a defendant in a particular case and a conviction follow, it will be'set aside, notwithstanding no injury can be pointed out. It is not so much what occurred during the trial, as what might have occurred when the judge.was absent and not exercising a supervising control over the proceedings." Yet the very court which decided that case found it inadvisable to adhere to it in another, ${ }^{105}$ in which the judge was absent but a minute, and only missed part of the defendant's answer to a question of the district attorney. In Georgia, at least, a brief absence is not of itself error; it is there held that the mere absence of the judge during the progress of the trial, when no objection is made, will not necessarily require the granting of a new trial, when the absence is only for a brief period of time and for

\footnotetext{
100 Ind. Ter. 234 (1904).

:0 56 Miss. 793 (1879).

${ }^{3 n} 46$ Tex. Cr. 34 (I904).

${ }^{30}$ Sioott v. State, 47 'Tex. Cr. 568 (1905).
} 
a necessary purpose; and in order for such absence to become reversible error, it must appear not only that objection was made to the judge's failure to suspend the trial, but that the absence of the judge resulted in some harm to the losing party. ${ }^{106}$

There is also a difference of opinion as to the effect of consent by the defendant or his counsel to the absence of the judge. One view is that by consenting to the absence, the defendant waives his right to the presence of the judge, and unless prejudice is shown, there is no error. ${ }^{107}$ But according to the weight of authority, neither the accused nor his counsel can consent to the absence, and such consent, if given, is not binding upon them. ${ }^{108}$

It is held that the effect of the. absence is not at all changed by the fact that the judge has directed someone else to perform his functions during his absence. In spite of that fact, a new trial must be granted, as the judge has no power to delegate judicial authority to another. ${ }^{100}$

The judge has entire control of the trial. If any good reason exists for his absence from the courtroom, after a trial has begun and before it ends, he can suspend proceedings until his return. A proper regard for the law on the part of the trial judge in a criminal case would lead him to suspend proceedings during any necessary absence. On the other hand, the rule requiring the judge to be present, has been applied too strictly, and many new trials have been unwisely granted. The absence of the judge during some part of the trial should not of itself be ground for reversal; the defendant should be required to show that he was prejudiced by some irregularity occurring during his absence, and he should be compelled to have an objection to the irregularity

${ }^{200}$ Pritchett v. State, $92 \mathrm{Ga} .65$ ( 1893 ); see also O'Shields v. State, 81 Ga. 301 (I888).

in State v. Hammer, I16 Ia. 284 (1902). (1877).

${ }^{20}$ Turbeville v. State, 56 Miss. 793 (1879) ; Meredith v. People, 84 IIl. 479

tw So where the judge called upon his daughter to preside during his absence, Goodman v. State, 47 Tex. Cr. 388 (IDO4); or upon an attorney, Ellerbe v. State, 74 Miss. 522 (1897); or allowed a verdict to be received in his absence by an attorney, Stewart v. State. 147 Ala. 137 (1006); or by telegraph directed the clerk to discharge a jury for inability to agree, State v. Jefferson, 66 N. C. 309 (1872). 
entered of record. A statute embodying this idea would give complete protection to the defendant, and at the same time prevent the reversal of many convictions. There is a possible constitutional objection to such legislation. It has been pointed out that some of the courts have based the rule requiring the presence of the judge at every stage of the proceedings upon the proposition that the defendant is entitled to be tried before a tribunal duly constituted, and that the absence of the judge works a disorganization of the court. It is not suggested that the defendant in a criminal case may be tried without a judge, but simply that an absence of the judge during part of the trial should not work a disorganization of the court. A reasonable interpretation of our constitutions would support such a statute.

\section{Lost INDictMent. -}

In some States it is provided by statute that when an indictment has been lost or destroyed, it shall be proper for the grand jury to find another indictment against the defendant. ${ }^{110}$ Most of the States, however, which have statutes on this subject, provide for a record of the indictment in a book provided for that purpose, and in case of the loss or destruction of the indictment, a certified copy of such record is by proper proceedings substituted for the original. ${ }^{111}$ In California the indictment is required to be filed rather than recorded, and if lost or destroyed a copy may be substituted for it. ${ }^{112}$ In Texas, the substitution of a copy of the original, or the finding of a new indictment is permitted in the alternative. ${ }^{113}$ The Texas statute in regard to substitution is quoted, as suggesting a concise method of procedure:

"When an indictment or information has been lost mislaid, mutilated, or obliterated, the district or county attorney may suggest the fact to the court, and the same shall be entered upon

${ }^{110}$ Wisconsin, Revised Statutes, 1911, \$4672; West Virginia, Code, 1906, \$4462; Rhode Island, General Laws, 1909, p. 1309, \$34; Kentucky, Statutes, 1903. \$I140; Alabama, Criminal Code, 1907, \$715\%. And see Rosenberger $v$. Comnionwealth, $118 \mathrm{~Pa} .77$ (1888).

"Sce for example Oklahoma, Revised Laws, 19to, Vol. II, \$6134; Montana, Revised Codes, 1907, \$9170; Mrississippi, Code, Ipor, \$it19.

"California, Penal Code, 1909, \$810.

"N Texas, Criminal Statutes, 1911, Art. 452. 
the minutes of the court, and in such case, another indictment or information may be substituted, upon the written statement of the district or county attorney, that it is substantially the same as that which has been lost, mislaid, mutilated, or obliterated."

The word "indictment" in the discussion which follows may be taken to refer also to the "information," as the rules of substitution are in each case the same.

The power of substitution has been said to exist independent of any statute. The doctrine is that there is an inherent power in the court to preserve and protect its jurisdiction when it has once attached, and to that end it may substitute any of its records which may be lost, by properly authenticated copies. This doctrine has been frequently applied to the substitution of lost indictments. ${ }^{114}$ In State ex rel. Null v. Circuit Court, ${ }^{115}$ on an application for an order supplying lost or stolen indictments, carbon copies were obtained from the State's attorney, and from the defendant's attorney, from which copies were made, and both the State's attorney and the clerk, who read the originals on the arraignment, and who made the certified copies for the defendant, testified that they believed the copies to be true and correct. The circuit court refused to certify the copies, and it was held that such certification might properly be compelled by mandamus, the court pointing out that "Every court must have inherent power to protect and preserve its own records; otherwise, it could not perform the functions for which it is created. The indictments in question became public records when filed with the clerk. The government, the defendant, and every inhabitant of the State was concerned in their preservation. When it was suggested that they had been lost or stolen, it was the duty of the court on its own motion, if its inherent power had not been otherwise invoked, to have caused the return of the original documents to their proper custodian, or failing in this, to have ascertained with reasonable certainty the contents of each, and ordered the filing of copies corresponding in every material respect with the originals. Such we believe to be the power and duty of every court existing by virtue of organized

\footnotetext{
"21' State v. Rivers, 58 Ia. 102 (1882).

${ }^{215}{ }_{104}$ N. W. Rep. I048 (S. D. 1905).
} 
law, with respect to all its records, whether civil or criminal, and that it cannot be deprived of such power or excused from performing such duty by any legislative enactment."

Statutes providing for substitution in case of a lost or destroyed indictment are held constitutional ;16 indeed, there appears to be no question but that substitution at any time after arraignment and plea is entirely proper. ${ }^{117}$ The matter of substitution before arraignment and plea is not so clear. In Ganaway v. State ${ }^{118}$ the solicitor for the State moved the court for leave to substitute a copy of the indictment for the original, which had been lost or destroyed; it was proved to the court that the paper offered was a correct copy of the original indictment, the court permitted the substitution, though the defendant had not then been arraigned. The supreme court held this error and denounced substitution in general in criminal cases in terms quite broad enough to forbid any substitution of a lost indictment. either before or after plea. But the same court in Bradford v. State, ${ }^{110}$ permitted substitution after arraignment and plea, and the court distinguished Ganaway v. State, holding substitution during the trial to be within the inherent power of the court. Ganaway v. State, however, has been mentioned in a number of cases in support of the proposition that substitution is improper before plea. The constitutional provision that no person can be held to answer a criminal charge unless on presentment or indictment of a grand jury has been invoked to show that substitution is improper where the defendant has not pleaded to the indictment. It is believed that this provision does not justify a distinction between substitution before and after plea. It is reasonable to require that the original indictment must have been filed or recorded, and unless this has been done there can be no substitution, if the indictment is lost or destroyed $;^{120}$ but after filing or

21" McGuire v. State, 76 Miss. 504 (1808); Schultz v. State, 15 Tex. Ap. 258 ( 1883 ).

"st State v. Heard, 49 La. An. 375 (1807); Schultz v. State, 15 Tex. Ap. 258 ( $188_{3}$ ); Harmon v. Territory, 9 Okla. 3I3 (1900); Mount v. State, 14 Ohio, 295 (1846); People v. Smith, 9 Cal. Ap. 224 (1908).

${ }^{13} 22$ Ala. 772 (1853).

21" 54 Ala. 230 (1875).

20 State v. Simpson, 67 Mo. 647 (1878). 
recording, substitution should be permitted before as well as after arraignment and plea. There are decisions so holding. ${ }^{121}$

There is a further difference of opinion as to whether the substituted copy must be an exact copy of the original indictment, or whether a substantial copy is sufficient. In States where the indictment is required to be recorded in full, it is a comparatively simple matter to produce an exact copy of the original; but where filing only is required, it might be difficult to procure an exact copy. It has been held that a substantial copy is sufficient. ${ }^{122}$ In State v. Thomas, ${ }^{123}$ on motion to substitute an alleged copy of a lost indictment, the attorney who made the motion testified that he never saw the original nor a copy of it, nor consulted with the attorney who drew it as to its contents; and that he drew the proposed substitute after examining and having returned to their custodian the minutes of the evidence before the grand jury. The attorney who drew the original testified that the substitute contained substantially all the allegations in the original, but that he could not say it was a true copy; that it was more voluminous than the original, and contained allegations not in the latter. The court held that the evidence introduced in support of the motion failed to show with the certainty that should be required in such a case that the proposed substitute was even a substantial copy of the indictment and the substitution was refused. This decision is undoubtedly correct upon its facts, but it is suggested that a substantial copy should be considered sufficient for all purposes, and that it is entirely unnecessary to require an exact copy of the lost indictment for the purpose of substitution.

Where the original indictment has been lost or destroyed, no further steps may be taken in the case unless substitution is made, or a new indictment found, where that is proper. Further proceedings in the absence of the missing document are

mithers v. State, 2I Tex. Cr. 210 (I886); McDowell v. State, 55 Tex. Cr. 596 (1909); Commonwealth v. Becker, 14 Pa. Super. Ct. 430 (1900).

Magee v. State, I4 Tex. Cr. 366 (1883); State v. Paul, 87 Mo. Ap. 47 (1900).

${ }^{128} 97$ Ia. 396 (1896). 
ground for a new trial. ${ }^{124}$ It is for the court to determine whether an exigency has arisen requiring substitution, ${ }^{125}$ and the substitution may be made only upon order of the court. ${ }^{126}$ So in State v. Burks, ${ }^{127}$ it was held:

"The clerk had no right to incorporate the paper purporting to be a copy of the indictment in the record even though requested to do so by the prosecuting attorney, and it cannot be treated as part of the record. It is one thing for a court to order a pleading substituted for one that is lost, after a hearing and after being satisfied that the substituted copy is the same or substantially the same as that which has been lost or destroyed, and quite another for one of the parties in vacation, or even in term time, to substitute a copy of a lost pleading without notice to his adversary and without the knowledge or permission of the court whose record is to be thus affected."

When it is proposed to substitute a copy for a lost indictment, it has been held that the defendant is entitled to be heard and to contest the substitution if he sees fit. ${ }^{128}$

The rule as to substitution is of course applied to indictments stolen ${ }^{129}$ or mutilated, ${ }^{130}$ as iwell as those lost or destroyed. On the other hand, where the indictment has been sent up with the record to the appellate court and has not been returned to the lower court in which a second trial is had, substitution has been held improper, as the original indictment is neither lost nor destroyed, and could be easily procured by suitable proceedings. ${ }^{131}$

Where by statute a new indictment by the grand jury follows the loss of the original, it is necessary also to provide for (1877).

${ }^{24}$ Freeman v. State, 6 Tex. Ap. 462 (1879); Buckner v. State, 56 Ind. 208

13 Epperson v. State, 5 Lea, 29I (Tenn. 1880).

2010 Clampitt v. State, 3 Tex. Ap. 638 (1878).

$2 \pi 132$ Mo. 363 (1896).

23 Bowers v. State, 45 Tex. Cr. 185 (1903).

20 Mount v. State, I4 Ohio, 295 (I846); State v. Paul, 87 Mo. Ap. 47 (1900); State v. Gardiner, I3 Lea, 134 (Tenn. 1884).

20 Huff v. State, 23 Tex. Cr. 291 (1887). Cf. Commonwealth v. Roland, 97 Mass. 506 ( 1867 ), where an indictment had been torn in three pieces, and the court permittcd the three pieces to be united and the restored instrument to be the basis of further proceedings.

12 Shehane v. State, 13 Tex. Ap. $\$ 33$ (1883); see also Boyd v. State, 6 Cold. I (Tenn. I868): 
the time within which such new indictment may be found, ${ }^{132}$ as otherwise the Statute of Limitations would sometimes prevent further prosecution; but in the process of substitution of an indictment, the Statute of Limitations presents no difficulties. Substitution in a pending case is not the institution of a new suit or a new prosecution; it is merely an ancillary proceeding in the action then pending. In other words, if the original indictment were returned at a time when the offense was not barred, it cannot avail a defendant, if the indictment becomes lost, that a motion to substitute was entertained at a time when, if treated as a new prosecution, the offense would be barred. ${ }^{285}$

It is held in Texas that the record must show that an order. of the court has been made allowing substitution, ${ }^{184}$ and that it must also show that the proposed substitution was in fact made. $^{135}$ In Rogers v. State ${ }^{130}$ the record showed that the original indictment had been lost, that the county attorney filed a written statement suggesting the loss and asking leave to substitute, and that the court, being satisfied that a copy submitted by the county attorney was correct, ordered that leave be granted. On appeal the court reversed the case, because "there was no judgment of the court declaring the fact of substitution. The record must show affirmatively the fact that the substitution as proposed by the county attorney was made." Where the record discloses the order of the court permitting substitution, it is suggested that the court might well presume that the substitution was in fact made.

The mere finding of the original indictment without an order of the court revoking the substitution does not affect the status of the case, which will proceed upon the substituted indictment until and unless such order is made. ${ }^{137}$ The court may,

10 Kentucky, Statutes, 1903, \$1140; Rhode Island, General L2ws, I909, p. 1309, \$34; West Virginia, Code, 1906, $\$ 4462$.

200 Thompson v. State, 54 Miss. 740 (1877); Brown v. State, 57 Tex. Cr. 570 (I910).

22 Graham v. State, 23 Tex. 550 (1875). 608 (1900).

200 Beardall v. State, 9 Tex. Ap. 262 (1880); Carter v. State, 41 Tex. Cr.

12* 11 Tex. Ap. 608 (1882).

in Branson v. State, $99 \mathrm{G} 2194$ (1896). 
however, direct that the trial proceed upon the original indictment, and will so order, if it is found pending the suhatitution. ${ }^{188}$

(To be Conciuded.)

Howard A. Lehmin.

Lare School, University of Pennsylvania.

19.0 Owens v. State, 46 Tex. Cr. I4 (1904). 